\title{
Commentary on immune system associated diseases caused by viruses: the role of EBV
}

\author{
Dale Barnard' and Joseph K.-K. Li' ${ }^{2 *}$ \\ 1 Institute for Antiviral Research, Department Animal, Dairy, and Veterinary Sciences, Utah State University, Logan, UT, USA \\ 2 Department of Biology, Utah State University, Logan, UT, USA \\ *Correspondence: joseph.li@usu.edu
}

\section{A commentary on}

Epstein-Barr virus, the immune system, and associated diseases

by Chen, M-R. (2011). Front. Microbio. 2:5. doi: 10.3389/fmicb.2011.00005

In her review using the human EpsteinBarr virus (EBV) as an example, Dr. Chen intends to illustrate how host immune systems have evolved in response to pathogens or in many cases co-evolved with pathogens. She discusses why EBV in most people causes what appears to be a self-limiting lymphoproliferative disease (or is it? See her discussion of autoimmune diseases and EBV), but in a very small proportion of individuals the virus causes malignant diseases of severe consequence. She reviews some of the plausible explanations that may include interactions of environmental and host genetic factors resulting in EBV associated malignancies. She points out that EBV may not merely transform B cells, but it could also impact the host immune system on a much more global basis than previously realized. She also suggests that EBV associated diseases, in lieu of reflecting the pathogenic potential of the virus, are actually a reflection of the genetic pre- disposition of certain populations to the modulate immune system inappropriately in response to the virus infection. She supports this notion by detailing the abnormal modulation of NKT cells when the host is infected with EBV. For example, she cites a study that shows that the frequencies of regulatory $\mathrm{CD} 8+\mathrm{NKT}$, but not $\mathrm{CD} 4+\mathrm{NKT}$ cells, in EBV associated Burkitt's lymphoma (BL) and nasopharyngeal carcinoma (NPC) patients are much lower than CD8 + NKT levels in healthy EBV carriers (Yuling et al., 2009), concluding that a skewed NKT cell response might modify the pathogenesis caused by the virus. She also supports her supposition that EBV pathogenesis is likely due to improper immune modulation in response to the infection by reviewing the data associating autoimmune diseases with EBV infections, especially focusing on multiple sclerosis (MS). She cites a study by Serafini et al. (2007) in which it was found that that almost $100 \%$ of the early onset MS cases with the secondary progressive phase contain dysregulated EBV infected plasma cells in MS brains. She also reviews other studies that describe atypical responses of MS patients who have been exposed to EBV. Nevertheless, the cause and effect link, EBV to MS, is still tenuous, yet intriguing. She concludes that the malignancies associated with EBV infection and especially the autoimmune diseases associated with EBV infection may result from human genetic variations that cause the host to differentially modulate the immune response to EBV infection to the detriment of the host.

\section{REFERENCES}

Yuling, H., Ruijing, X., Li, L., Xiang, J., Rui, Z., Yujuan, W., Lijun, Z., Chunxian, D., Xinti, T., Wei, X., Lang, C., Yanping, J., Tao, X., Mengjun, W., Jie, X., Youxin, J., and Jinquan, T. (2009). EBV-induced human CD8 ${ }^{+}$ NKT cells suppress tumorigenesis by EBV associated malignancies. Cancer Res. 69, 7935-7944.

Serafini, B., Rosicarelli, B., Franciotta, D., Magliozzi, R., Reynolds, R., Cinque, P., Andreoni, L., Trivedi, P., Salvetti, M., Faggioni, A., and Aloisi, F. (2007). Dysregulated Epstein-Barr virus infection in the multiple sclerosis brain. J. Exp. Med. 204, 2899-2912.

Received: 02 February 2011; accepted: 04 February 2011; published online: 16 February 2011.

Citation: Barnard D and Li JK-K (2011) Commentary on immune system associated diseases caused by viruses: the role of EBV. Front. Microbio. 2:28. doi: 10.3389/ fmicb.2011.00028

This article was submitted to Frontiers in Virology, a specialty of Frontiers in Microbiology.

Copyright $\odot 2011$ Barnard and Li. This is an open-access article subject to an exclusive license agreement between the authors and Frontiers MediaSA, which permits unrestricted use, distribution, and reproduction in any medium, provided the original authors and source are credited. 